\title{
The Implementation of Portfolio Assessment to Increase Critical Thinking Ability for High School Students on Human Coordination System Material
}

\author{
Annisa Tiara Linanti ${ }^{\bowtie}$, Saiful Ridlo, Siti Harnina Bintari \\ Pascasarjana, Universitas Negeri Semarang, Indonesia
}

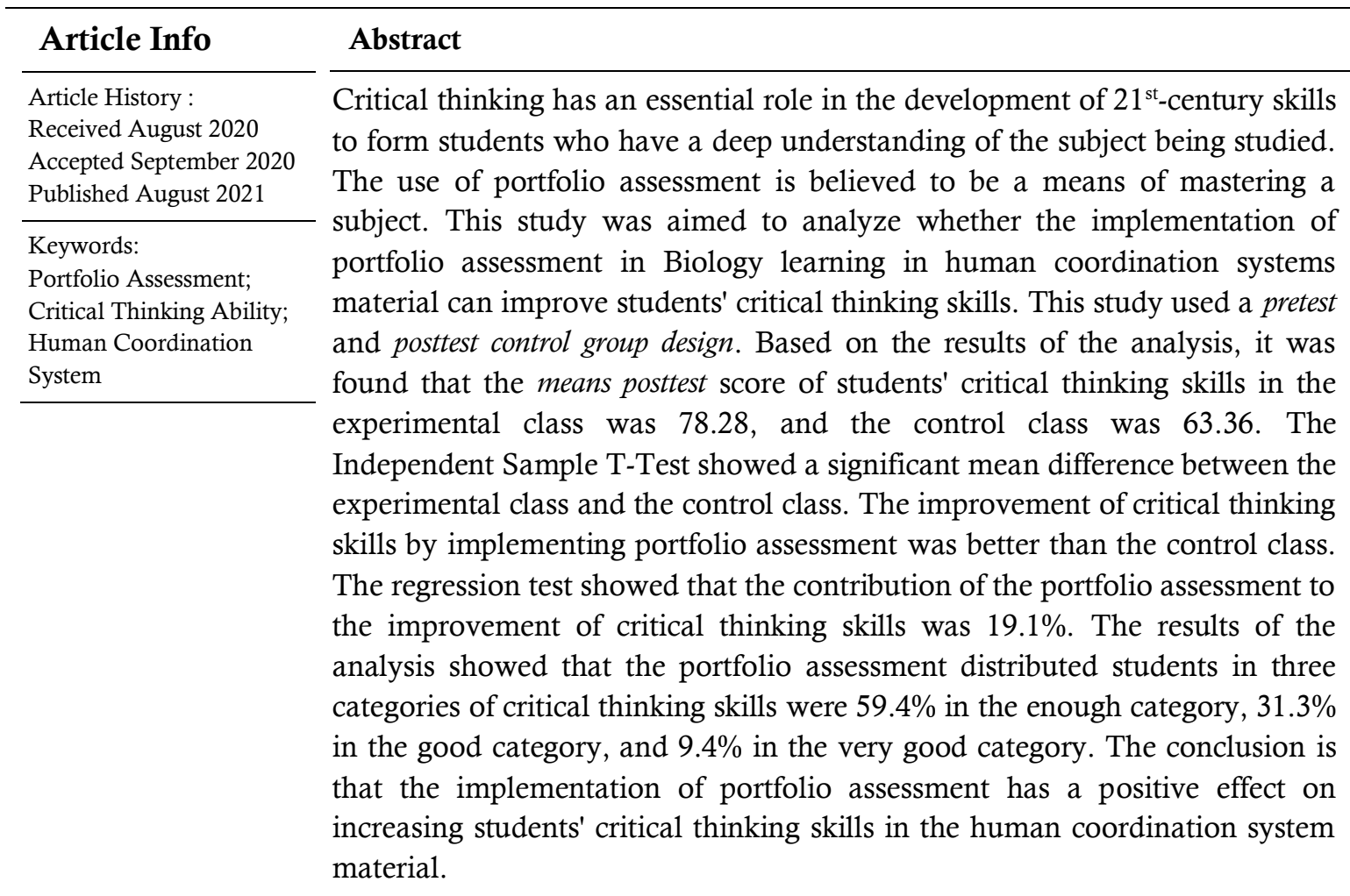

\footnotetext{
$\triangle$ correspondence :

Pascasarjana, Universitas Negeri Semarang, Indonesia

Jalan Kelud Utara III No.37, Semarang, Jawa Tengah, Indonesia

50237

E-mail: annisatiara79@gmail.com
} 


\section{INTRODUCTION}

The Critical thinking ability is one of the thinking skills needed by students in dealing with the rapid current flow of information. Critical thinking is needed to form a person who can ask questions, express opinions, look for factual evidence, and be able to evaluate any information obtained without merely accepting it as truth (Adnyana, 2012). Kim et al. (2012) stated that critical thinking has a vital role in helping students construct their knowledge in selecting information and arguments. Students with critical thinking skills will be able to analyze information based on clear facts and reasons. This condition makes it easier for students to understand something that is being studied in the learning process.

Critical thinking is a competency to think rationally and reflectively that students need in learning activities (Redhana, 2010). It is in line with the opinion of Ildayanti (2017), which states that critical thinking is the right direction for students to understand learning material. The purpose of critical thinking is to ensure as far as possible the valid and correct thinking of students is formed in analyzing a problem faced in the learning process (Faiz, 2012). In summary, critical thinking plays a role in increasing in-depth understanding of learning materials, including in the context of learning Biology.

Human coordination system material is one of the Biology learning materials for class XI in the even semester. The human coordination system includes sub-topics, namely the nervous system, hormone system, and sensory system. According to Cimer (2012), students need special learning techniques to make it easier to understand the human coordination system material. It is because the material of the human coordination system involves a lot of complex discussions related to several detailed physiological processes of the human body. (Aminy et al., 2017).

Based on the results of interview with a Biology teacher in class XI at SMA Negeri 1 Tanah Abang, Pali, South Sumatra, it is known that teachers had not trained or developed students' critical thinking skills maximally. The learning process carried out by the teacher was still dominated by the ability of students to remember a biological concept. The teacher argues that smart and critical students only owned the ability to think critically. All students can own the ability to think critically without specific characteristics. Teachers only need to practice or get used to thinking actively and gradually in each learning development of students. Therefore, a learning activity that can facilitate students in developing and controlling their thinking skills is needed. Idris et al. (2014) explained that the active and independent thinking control of students would affect sharpening their thinking. One alternative learning activity that can be implemented based on this objective is portfolio assessment.

Portfolio assessment is a form of class-based assessment (assessment for learning) of a set of students' assignment within a particular time which aims to determine the learning development of students (Surapranata \& Hatta, 2006). Giving assignment in a systematic and organized way is believed to improve critical thinking skills because students are trained to think more actively in doing the tasks related to learning material (Ningtyas \& Tenzer, 2018). It is in line with Sadikin (2016), which states that the implementation of portfolio assessment encourages an in-depth learning process. In-depth learning is meant in the form of action to evaluate situations, problems, or arguments, and to choose patterns of investigation that produce the best answers that can be obtained. These actions are part of the scope of critical thinking skills (Dwijananti \& Yulianti, 2010). Lukitasari et al. (2013) stated that portfolio assessment provides opportunities for students to identify, focus, analyze, synthesize, and create based on a subject being studied, where all aspects are within the scope of critical thinking skills.

The most dominant assessment component in the implementation of portfolio assessment is the presence of feedback and self-assessment (Idris et al., 2014). In other words, students not only have selfcontrol but also get input or feedback from the teacher in developing their critical thinking skills.

The purpose of this research was to analyze the implementation of portfolio assessment in increasing the critical thinking skills of high school students in the human coordination system material. The significance of this research was to obtain alternative learning methods by prioritizing the use of assessment in monitoring learning 
development, especially the students' critical thinking skills.

\section{METHODS}

The study was conducted in May until June 2020. The study used a Pretest-Posttest Control Group Design (Sugiyono, 2016) with the following scheme.

\begin{tabular}{|cccc|}
\hline $\mathrm{E}$ & $\mathrm{O} 1$ & $\mathrm{X}$ & $\mathrm{O} 2$ \\
$\mathrm{~K}$ & $\mathrm{O} 3$ & - & $\mathrm{O} 4$ \\
\hline
\end{tabular}

Figure 1. Research Design Schematic

$$
\begin{aligned}
& \text { Information: } \\
\mathrm{E}= & \text { Experiment } \\
\mathrm{K}= & \text { Control } \\
\mathrm{O} 1= & \text { Pretest } \\
\mathrm{O} 2= & \text { Posttest } \\
\mathrm{X}= & \text { treatment (portfolio assessment } \\
& \text { implementation in a scientific } \\
& \text { approach) } \\
\mathrm{O} 3= & \text { Pretest } \\
\mathrm{O} 4= & \text { Posttest } \\
-= & \text { There is no treatment (scientific } \\
& \text { learning approach) }
\end{aligned}
$$

The population in this study was students of class XI SMA Negeri 1 Tanah Abang, Pali, South Sumatra in the 2019/2020 school year. Sampling was done by random sampling technique by taking two classes. Class XI MIPA 2 was the experimental class and class XI MIPA 1 was the control class. Each class consisted of 32 students.

The independent variable in this study was the learning design. The dependent variable was the critical thinking ability of students. Meanwhile, the control variables were the curriculum used, the teacher, the learning approach, the learning materials, the teaching materials used, and the number of lesson hours.

The data collection methods were the test and documentation method. The test method was an essay test that consists of 10 items which were used to obtain students' critical thinking skills data. Moreover, the documentation method was used to list names, the number of students, and all data required in the study.

The critical thinking skills of students can be identified by analyzing the answers written by students in the form of subjective tests (essay test). The data from the students' answers were analyzed based on the assessment guidelines that had been made. Assessment guidelines were made by giving interval scores $0-4$ with specific criteria. Scoring was followed by calculations using the following formula.

Average $=\frac{\mathrm{R}}{\mathrm{SM}} \times 100 \%$

Information:

Average : Percentage

R : : The score obtained by students

SM : Maximum test score

100 : Fixed number

The mean of critical thinking skills value in each student who has been obtained then qualified into the Pritasari (2011) category.

Table 1. Percentage of Critical Thinking Ability Category

\begin{tabular}{ll}
\hline Value Range & Category \\
\hline $90 \leq \mathrm{A} \leq 100$ & Very Good \\
$75 \leq \mathrm{B}<90$ & Good \\
$55 \leq \mathrm{C}<75$ & Enough \\
$40 \leq \mathrm{D}<55$ & Poor \\
$0 \leq \mathrm{E}<40$ & Very Poor \\
\hline
\end{tabular}

Critical thinking skills data were analyzed using the $\mathrm{N}$-gain test and the $\mathrm{t}$-test to determine whether there was a critical thinking skill increase between the experimental class and the control class. The increase of the pretest and posttest mean score was calculated using the following Meltzer (2002) formula.

$\mathrm{N}$ gain $=\frac{\text { posttest score }- \text { pretest score }}{\text { maksimum score }- \text { pretest score }}$

The $N$ gain values that have been obtained were categorized in Table 2 below.

Table 2. Category of Gain Index

\begin{tabular}{ll}
\hline Gain Index Value & Category \\
\hline$>0.7$ & High \\
$0.3-0.7$ & Moderate \\
$<0.3$ & Low \\
\hline
\end{tabular}

After finding an increase, the calculation was continued with a regression test to determine the contribution of portfolio assessment implementation to the critical thinking skills value. The t-test and regression test was performed using SPSS 21 for windows. 


\section{RESULT AND DISCUSSION}

The data analysis began with the homogeneity test analysis and the data normality test of pretest on students' critical thinking ability. In succession, the homogeneity and normality tests were carried out with the help of the SPSS application through the one way ANOVA test and the Shapiro-Wilk test. It was obtained; the mean score of students pretest in the sample class was not significantly different with a significance value of $0.297>0.05$. It shows that the sample came from a homogeneous population. Also, the data normality test analysis showed that the significance value for the experimental group was 0.096 and the control group was $0.105>0.05$, which indicated that the experimental and control group data were normally distributed.

Furthermore, the data analysis of the gain value (the difference between the posttest and pretest scores) of students' critical thinking skills in each class showed a significant difference. The mean score of critical thinking ability in the experimental class was higher than the control class. The mean score of pretest, posttest, gain, $\mathrm{N}$-gain, along with the $N$-gain category of the sample class can be seen in Table 3.

Table 3. Summary of Mean Score of Pretest, Posttest, Gain, N-Gain, N-Gain Category

\begin{tabular}{lllllll}
\hline \multirow{2}{*}{ Class } & \multirow{2}{*}{$\mathrm{N}$} & \multicolumn{2}{l}{ Average } & & & \\
\cline { 3 - 4 } & & Pretest & Posttest & Gain & N-Gain & N-Gain Category \\
\hline Experiment & 32 & 44.06 & 78.28 & 34.22 & 0.61 & Moderate \\
Control & 32 & 37.03 & 63.36 & 26.33 & 0.42 & Moderate \\
\hline
\end{tabular}

Based on Table 3, it was found that the means posttest score of students' critical thinking skills in the experimental class was 78.28 and the control class was 63.36. Table 3 also showed that the increase in the mean score from pretest to posttest in the experimental class is higher than the control class. The experimental class has a gain value of 34.22 , which was higher than the control class of

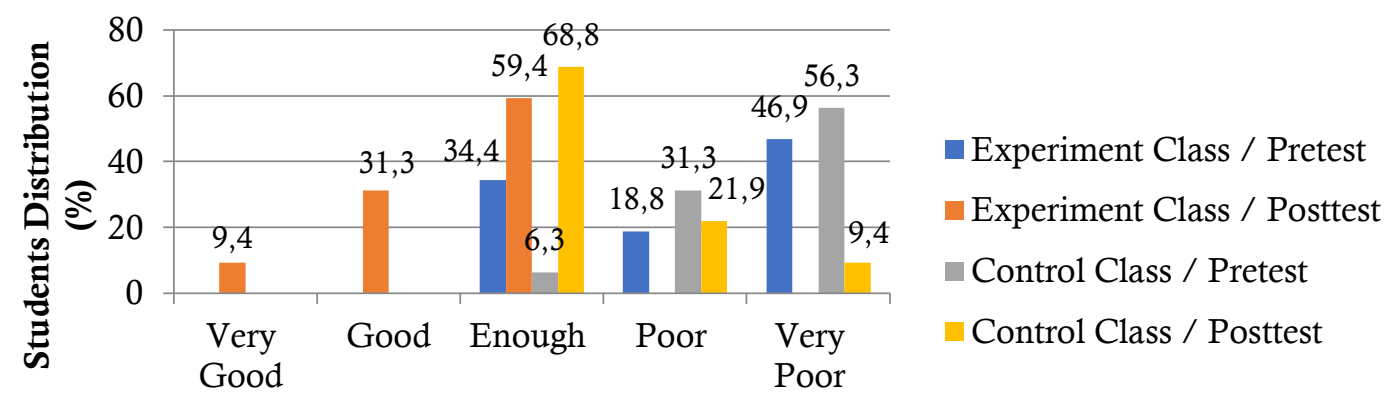

Critical Thinking Ability Category
26.33. In general, the increase of the pretest and posttest mean score in the two sample classes was in the moderate $\mathrm{N}$-gain category. The experimental class has an $\mathrm{N}$-gain value of 0.61 , and the control class is 0.42 . The results are supported by the distribution of students in the critical thinking skills category is shown in Figure 1 below.
Based on Figure 1, the pretest scores of critical thinking skills between the experimental class and the control class are in the same three categories, namely very poor, poor, and enough. The difference in critical thinking skills category occurred in the posttest scores. The posttest score of the experimental class classifies students into the category of enough, good, and very good with a percentage of $59.4 \%$; $31.3 \%$; and $9.4 \%$. Meanwhile, the control class does not experience a change in the category as well as

Figure 1. Students Distribution in the Critical Thinking Ability Category

the pretest score. Thus, there is a positive effect between portfolio assessment and increased critical thinking skills.

Data analysis continued with hypothesis testing to prove that there was a significant difference or not between the critical thinking skills value between the experimental class and the control class statistically. The hypothesis test began with a data normality test using the Shapiro-Wilk test by comparing the gain values in the two sample 
classes. The results obtained were the significance value of the experimental class and the control class, respectively, 0.292 and $0.299>0.05$, which indicates that the data for the two samples were normally distributed.

Hypothesis testing through the independentsample T-test shows that there were significant differences in the critical thinking skills value between the experimental class and the control class. The results of the analysis of the hypothesis test showed that the t-count with a probability was $0.012<0.05$, it can be concluded that there was a significant difference in critical thinking skills value between the experimental class and the control class.
The critical thinking ability of students in the human coordination system material has increased significantly through the implementation of portfolio assessment. Students' critical thinking skills are getting better after the implementation of portfolio assessment. It is in line with research by Ningtyas and Tenzer (2018) and research by Parwoto et al. (2019) which states that the implementation of portfolio assessment causes the critical thinking power of students to be higher. The contribution of portfolio assessment to increasing critical thinking skills is shown by the results of the regression test in Table 4 below.

Table 4. Summary of Mean Score of Pretest, Posttest, Gain, N-Gain, N-Gain Category

\begin{tabular}{lllll}
\hline Model & $\mathrm{R}$ & R Square & Adjusted R Square & Std. Error of the Estimate \\
\hline 1 & $0.437^{\mathrm{a}}$ & 0.191 & 0.164 & 6.49455 \\
\hline \multicolumn{4}{r}{ a. } & Predictors: (Constant). Portfolio
\end{tabular}

Based on Table 4, it is known that the value of the correlation/relationship (R) is 0.437 with a determination coefficient of 0.191 . It shows that the effect of the independent variable (portfolio assessment) on the dependent variable (critical thinking ability value) is $19.1 \%$. It can be interpreted that the critical thinking skills of students are honed by implementing portfolio assessments. It is in line with the results of research by Pantiwati (2013) which states that portfolio assessment as a form of authentic assessment that is implemented consistently in learning can support the development of critical thinking of students. Through the application of portfolio assessment in the learning process, it allows students to evaluate situations, problems, or arguments, and choose patterns of investigation in finding the best answers that can be obtained (Dwijananti \& Yulianti, 2010).

One form of the task in the implementation of portfolio assessment in this study was summarizing task. According to Ningtyas et al. (2018), the summarizing task can train students' critical thinking skills in making arguments, making deductions, induction, and evaluating. Through summarizing assignments, students are allowed to read, collect information, analyze and evaluate information obtained related to learning materials. Summarizing activities that come from the book and the internet sources requires students to remember, retrieve, and link their previous knowledge and analyze this information to build new concepts. The summarizing task becomes an alternative for students in developing their critical thinking skills (An \& Ying, 2009).

Self-reflection is an essential part of developing critical thinking skills. It is supported by the statement of Ennis (2011), who argues that critical thinking emphasizes thinking patterns that are reasoned and reflective. A similar opinion by Hasanah (2016) who states that self-reflection activities can empower critical thinking skills in deciding and implementing actions that students will take to correct their deficiencies in subsequent learning.

The manifestations of self-reflection activities in this study were quizzes and formative tests at each meeting. Quiz giving was done at the beginning of the learning activity. It was aimed to determine the prior knowledge of students. The initial knowledge becomes the basis for the teacher in acting, whether it provides reinforcement of the correct initial knowledge or correcting wrong knowledge. The formative test given was aimed to find out the final knowledge obtained by students after participating in the learning process. In summary, giving quizzes and formative tests is a form of portfolio assessment that emphasizes the elements of feedback and self-assessment (Idris et al., 2014). 
The basis for determining the regression thinking skills refers to Table 5 below. equation between portfolio assessment and critical

Table 5. Value of the Regression Equation between Portfolios and Critical Thinking Ability

\begin{tabular}{lllllll}
\hline Model & & \multicolumn{2}{l}{ Unstandardized Coefficients } & \multicolumn{2}{l}{ Standardized Coefficients } & t \\
& & $\mathrm{B}$ & Std. Error & Beta & Sig. \\
\hline 1 & (Constant) & 61.794 & 5.239 & & 11.796 & 0.000 \\
& Portofolio & 0.237 & 0.089 & 0.437 & 2.660 & 0.012 \\
\hline
\end{tabular}

a. Dependent Variable: Posttest

Based on Table 5, Constant (a) is 61.794 , and the Portfolio value $(b /$ regression coefficient) is 0.237 . Thus the regression equation can be written as follows.

$$
\mathrm{Y}^{\prime}=61,794+0,237 \mathrm{X}
$$

The regression equation means that the Constant of 61.794 is the consistent value of the critical thinking ability variable, which is 61.794 . The $\mathrm{X}$ regression coefficient of 0.237 states that for every $1 \%$ increase in portfolio value, the value of critical thinking skills increases by 0.237 . The regression coefficient was positive. Thus there was a positive effect of variable $\mathrm{X}$ (portfolio assessment) on Y (critical thinking ability). The results of this study are relevant to the research results of Utami $e t$ al. (2018). They argue that the application of portfolio assessment is effective in improving the critical thinking skills of students in learning biology in the immune system chapter. Further, research Rahmi et al. (2017) and Parwoto et al. (2019) emphasized that there was an increase in critical thinking as part of students' higher-order thinking skills after the implementation of portfolio assessment.

The effect of portfolio assessment on students' critical thinking skills is shown by students who complete a set of tasks. They can analyze, evaluate, and convey their ideas obtained during learning. It is reinforced by Dewi's (2016) research which confirms that portfolio assessment trains a student to analyze, organize, evaluate, and describe their learning experience so that critical thinking skills can be developed. It is in line with Maesuri (2002). One of the advantages of portfolios as a means for students to evaluate themselves independently (self-assessment). By implementing a portfolio assessment, students' critical thinking skills can be trained and developed in a better way.

\section{CONCLUSION}

This study concluded that there is a significant difference in critical thinking skills value between the experimental class and the control class. Students' critical thinking skills in the experimental class is better than the control class. Thus, the implementation of portfolio assessment has a positive effect on increasing students' critical thinking skills in the human coordination system material.

\section{REFERENCES}

Aminy, R., Huzaifah, S., \& Santri, D. J. (2017). "Pengembangan Materi Pembelajaran Sistem Koordinasi Manusia Memanfaatkan Fitur Edmodo untuk Sekolah Menengah Atas". Jurnal Pembelajaran Biologi, 4(1): 28-42.

Adnyana, G. P. (2012). "Keterampilan Berpikir Kritis dan Pemahaman Konsep Siswa pada Model Siklus Belajar Hipotesis Deduktif". Jurnal Pendidikan dan Pengajaran, 45(3): 201-209.

Cimer, A. (2012). "What Makes Biology Learning Difficult and Effective: Students' View". Educational Research and Reviews, 3(7): 61-71.

Dewi, K. (2016). "Improving Critical Thinking in Academic Writing through Portfolio in Higher Education". 1st UPI International Conference on Sociology Education (UPI ICSE 2015), 411-415.

Ennis, R. H. (2011). The Nature of Critical Thinking: An Outline of Critical Thinking Dispositions and Abilities. http://faculty.education.illioniz.edu/rhennis/doc uments/TheNatureofCriticalThinking51711000.p df (diunduh 12 Januari 2020).

Faiz, F. (2012). Thinking Skill: Pengantar Berpikir Kritis. Yogyakarta: SUKA Press.

Dwijananti, P. \& Yulianti, D. (2010). Pengembangan Kemampuan Berpikir Kritis Mahasiswa melalui Pembelajaran Problem Based Instruction pada Mata Kuliah Fisika Lingkungan. Jurnal Pendidikan Fisika Indonesia, 6(2): 108-114.

Hasanah, U., Susilo, H., \& Suwono, H. (2016). "Pengaruh Pembelajaran Inkuiri dengan Asesmen 
Portofolio terhadap Kemampuan Berpikir Kritis dan Hasil Belajar Kognitif Mahasiswa”. Jurnal Pendidikan: Teori, Penelitian, dan Pengembangan, 1(10): 1952-1957.

Idris, T., Sriyati, S., \& Rahmat, A. (2014). "Pengaruh Asesmen Portofolio terhadap Habits of Mind dan Penguasaan Konsep Biologi Siswa Kelas XI". Jurnal Pendidikan Biologi, 6(1): 63-67.

Ildayanti, (2017). "Hubungan Kemampuan Berpikir Kritis dan Kesadaran Metakognitif dengan Hail Belajar Biologi Peserta didik Kelas XI IPA SMA Negeri di Kabuoaten Pinrang”. Tesis. Makassar: Program Pacsarjana Universitas Negeri Makassar.

Kim, K. Priya S., Susan M. L. \& Kevin P. F. (2012). "Effects of Active Learning on Enhancing Student Critical Thinking in an Undergraduate General Science Course". Journal of Innovation High Education, 1(38):223-235.

Lukitasari, M., Handhika, J., \& Murtafiah, W. (2016). Analisis Kebutuhan E-Portofolio Berbasis Metakognisi untuk Meningkatkan Keterampilan Abad 21. Proceeding Biology Education Conference, 13(1): 93-96.

Meltzer, D. E. (2002). Normalized learning gain: a key measure of student learning. Department of Physics and Astronomy: Low State University.

Ningtyas, D. A. \& Tenzer, A. (2018). "Pengaruh Penerapan Asesmen Portofolio Proses dalam Model Inkuiri Terbimbing terhadap Keterampilan Berpikir Kritis dan Hasil Belajar Biologi Peserta didik Kelas X SMA Negeri 2 Batu". Jurnal Pendidikan Biologi, 9(1): 1-9.

Parwoto, Rusmayadi, \& Bakhtiar, M. Y. (2019). "Pengaruh Asesmen Portofolio berbasis ELearning dan Minat Baca terhadap Kemampuan
Berpikir Kritis Mahasiswa PGPAUD FIP UNM". Prosiding Seminar Nasional LP2M UNM, 502-505.

Pritasari, A. D. C. (2011). "Upaya Meningkatkan Kemampuan Berpikir Kritis Siswa Kelas XI IPA 2 Sekolah Menengah Atas Negeri 8 Yogyakarta pada Pembelajaran Matematika melalui Pembelajaran Kooperatif Tipe Group Investigation (GI)". Jurnal Bionature, 15(2): 81-89.

Rahmi, Y. L. \& Alberida, H. (2017). "Peningkatan Keterampilan Berpikir Tingkat Tinggi Mahasiswa melalui Penerapan Asesmen Portofolio pada Mata Kuliah Telaah Kurikulum dan Buku Ajar Biologi”. Bioeducation Journal, 1(1): 22-33.

Redhana, I. W., Sudiatmika, A. A. I. A. R., \& Artawan, I. K. (2010). "Pengembangan Perangkat Pembelajaran Berbasis Masalah dan Pertanyaan Socratik untuk Meningkatkan Keterampilan Berpikir Kritis Siswa SMP". Jurnal Pendidikan dan Pengajaran, 42(3): 151-159.

Sadikin, A., Aina, M., \& Hakim, N. (2016). "Penerapan Asesmen Berbasis Portofolio dan Jurnal Belajar untuk Meningkatkan Kemampuan Metakognitif dan Motivasi Belajar Mahapeserta didik pada Mata Kuliah Perencanaan Pengajaran Biologi. Jurnal Biodik. 2(2): 50-61.

Sugiyono. (2016). Metode penelitian pendidikan pendekatan kuantitatif, kualitatif, dan R\&D. Bandung: Penerbit Alfabeta.

Surapranata, S. \& Hatta, M. (2006). Penilaian Portofolio Implementasi Kurikulum. Bandung: PT Remaja Rosdakarya.

Utami, H. D., Yuniastuti, A., \& Rudyatmi, E. (2018). "Efektivitas Model Pembelajaran Problem Based Learning dengan Asesmen Portofolio pada Materi Sistem Imum". UNNES Journal Biology Education, 7(2): 202-208. 